\title{
GODNOŚĆ LUDZI WYKLUCZONYCH, NA PERYFERIACH I... W 100-LECIE ODZYSKANIA NIEPODLEGŁOŚCI PRZEZ POLSKĘ
}

\section{DIGNITY OF THE EXCLUDED PEOPLE, ON THE PERIPHERALS AND... IN THE 100 YEARS OF INDEPENDENCE OF POLAND}

The dignity of a man who fits into his subjective existence is imperishable and irreducible. It implies awareness of subjectivity, the ability to reflect, identity, historicity, freedom, autonomy of the relationship.

In individual dignity, man experiences belonging to a group whose functioning is often dictated by national dignity. A hundred years of Poles' independence showed that the history of the nation affects the maintenance of the sense of individual dignity and the changing circumstances of life, often dictated by persecution or life on the periphery of this dignity, can not threaten.

In order to show the dignity carried out in the period of one hundred years of independence, the following problems have been emphasized: the principle of human dignity (1), dignity as the basis of social life (2.), dignity crippled and trampled - exile, exile, emigration, periphery (3.) in defense of dignity (4.).

Key words: dignity, human person, nation, history, Church.

Godność to szczególna wartość człowieka. Z języka łacińskiego dignitas - to stała i nieredukowalna wartość przysługująca człowiekowi w sposób trwały, niezbywalny i zobowiązujący. Uzasadnia i usensownia życie człowieka. Osobowa godność człowieka świadczy o jego podmiotowym istnieniu. Zawiera się w tym, że człowiek jest sobą tzn. ma zdolność refleksji o sobie, uświadamia swoją 
podmiotowość, tożsamość, historyczność, jest autonomiczny i jednocześnie pozostaje w relacjach interpersonalnych. Relacje te tworzy z grupą, do której przynależy, o charakterze zawodowym, klasowym, czy narodowym. Jest jednostką społeczną. Godność przejawia się także w tym, że człowiek autonomicznie panuje nad własnymi czynami, stawia cele i je realizuje.

W 100-lecie niepodległości Polski warto o godności osoby ludzkiej mówić, bo ona była i jest priorytetem funkcjonowania narodu polskiego.

\section{Zasada godności osoby ludzkiej}

Każdy człowiek jest osobą. Według Boecjusza oznacza to, że jest indywidualną substancją natury rozumnej, co można interpretować, że człowiek jest świadomym i wolnym podmiotem swoich czynów, odpowiedzialnym za siebie, za drugiego człowieka i świat. Jest to właściwość, która stanowi o godności, tzn. o ontycznej i powinnościowej relacji do Boga, ludzkiej społeczności i świata. O godności człowieka można mówić w aspekcie filozoficznym, psychologicznym, teologicznym i prawnym ${ }^{1}$.

Filozoficznie dotyka wymiaru ontologiczno-personalistycznego. Fakt bycia człowiekiem jako bytu osobowego zawiera podstawę do uznania godności niezależnie od przynależności do rasy lub klasy, religii, wykształcenia, stanu posiadania, a nawet poziomu moralności. Człowiek na poziomie argumentów rozumu szuka uzasadnienia i odpowiedzi na pytanie o istotę godności, znajdując odpowiedź w doświadczeniu siebie i w intelektualnej refleksji. Ta mobilizuje do potrzeby odróżnienia życia osobowego od nieosobowego. Istota godności nie zawiera się w sumie komórek, tkanek, narządów, które warunkują życie biologiczne człowieka. Człowiek to zintegrowany byt osobowy, złożony z ciała, duszy i ducha, który jest podstawową zasadą istnienia. Godność bazuje na wartości wewnętrznej ludzkiego życia. Jest celem samym w sobie. Życie człowieka jest nieocenione, ma w sobie godność, której nie da się złożyć w ofierze, wyprzedać lub wykorzystać na potrzeby innego celu. Już św. Tomasz z Akwinu, mówiąc o godności, rozróżniał pomiędzy dignitas (godność) a utilitas (pożytek). Dignitas significat bonitatem alicujus propter seipsum, utilitas vero propter aliud². Godność oznacza dobroć posiadaną ze względu na samego siebie, pożytek natomiast służy innym.

Romano Guardini (1885-1968) - teolog i filozof religii, przypominał, że „człowiek to realność metafizyczna, nie tylko psychologiczna; realność ta ze swej istoty - nie zależy ani od wieku, ani od stanu psychicznego, ani też od

Z. Chlewiński, Z.Zaleski, Godność, [w:] Encyklopedia Katolicka, t. 5, Lublin 1989, s. 1232.

Tomasz z Akwinu, Scriptum super sententiis, lib. 3 d. 35 q. 1 a. 4 qc 1 co. 
szczególnych talentów, w jakie natura wyposażyła dany podmiot (...). To bycie osobą decyduje o godności każdego, poszczególnego człowieka”3. Godność osoby ludzkiej jest niezbywalna. Prymat wynikający z godności człowieka to prymat osoby nad rzeczą, być nad mieć, czyli istnienia nad posiadaniem.

Filozoficzna koncepcja godności człowieka znajduje swoje poszerzenie i pogłębienie w argumentacji teologicznej. W relacji do Boga człowiek jest Jego obrazem i podobieństwem $(\mathrm{Rd} z 1,26)$. Tak jest redagowana prawda o człowieku w fundamentalnej teorii teologii dogmatycznej zwanej kreacjonizmem. Wydarzenie stwórczego aktu rzutuje na teologiczne źródło godności osoby ludzkiej. Człowiek nie jest Bogiem, jak niektórzy współcześni naukowcy myślą. Jest stworzeniem. Pomiędzy Bogiem a człowiekiem istnieje relacja zależności, która kształtuje bytowe podobieństwo człowieka do Boga. W akcie stwórczym zawiera się przeznaczenie człowieka do życia w Bogu aż po wieczność. Wzniosłość tego nadprzyrodzonego powołania ukazuje wielkość i niezastępowalną wartość godności osoby ludzkiej. Sam Bóg podporządkowuje się nadanym przez siebie regułom ludzkiej godności, co widać nawet w tak dramatycznej sytuacji, gdy to on pozwala człowiekowi na to, by ten zupełnie i ostatecznie się go wyparł. Indywidualna godność człowieka jest zatem związana z jego własną odpowiedzialnością. Z tą odpowiedzialnością staje sam na sam wobec Boga i innych.

Została ona wzmocniona wraz z Wcieleniem Jezusa Chrystusa w ludzką naturę. Zapoczątkowane życie Syna Bożego poprzez misterium Wcielenia i dopełnione śmiercią i Zmartwychwstaniem przyczyniło się do podniesienia godności człowieka do udziału w Misterium Paschalnym, w którym Chrystus obdarza człowieka pełnią życia (J 12, 32). Pierwotna doskonałość i niczym nienaruszona godność człowieka, utracona przez oddalenie się od Boga, została w Chrystusie na nowo przywrócona, zyskując w zjednoczeniu z Nim swoją pełnię. Zjednoczony w Chrystusie człowiek doświadcza wsparcia ze strony Ducha Świętego. Dzięki Duchowi Świętemu człowiek wchodzi w nowość życia i staje się mieszkaniem Ducha Świętego, żywą Świątynią Boga" . „W komunii łaski z Trójcą Świętą rozszerza się niejako wewnętrzna przestrzeń życiowa człowieka wyniesiona do nadprzyrodzonej godności życia Bożego" ${ }^{5}$ - napisze w Encyklice Dominum et Vivificantem św. Jan Paweł II. Pomijanie wymiaru

\footnotetext{
3 R. Guardini, I diritti del nascituro, "Studi cattolici" 5/6 (1974), s. 82-83.

4 Duch Święty jest Tym, który przenika i dynamizuje życie wewnątrz Trójcy Świętej. W pewnym sensie w Jego Osobie następuje wewnątrzboska perychoreza (przenikanie). Duch Święty także sprawia, że człowiek dzięki życiu sakramentalnemu w Duchu Świętym partycypuje w osobowej miłości Boga, tym samym stając się żywą Świątynią Boga. Por. K. Gąsecki, Jesteśmy napetnieni Duchem Chrystusa w sakramentach Kościoła, Pelplin 2018, s. 8.

5 Por. Jan Paweł II, Dominum et Vivificantem, 58.
} 
nadprzyrodzonego zniekształca i narusza godność człowieka, dotyka ona bowiem porządku naturalnego i nadnaturalnego.

Człowiek jest jedynym w świecie bytem cielesno-duchowym, niepowtarzalnym, najdoskonalszym, wśród innych złożonych z materii i formy. Jest jednością ciała i duszy. Ta ostatnia jest w nim zasadą życia, formą substancjalną. Dzięki czynnikowi duchowemu człowiek jest osobą. Płynie z tego powinność przejawiająca się w postępowaniu w jedności ducha i ciała, podporządkowaniu instynktów rozumowi. W relacjach międzyludzkich dzięki godności człowiek jest podmiotem, nie przedmiotem, celem, nie środkiem. Dzięki godności osoby człowiek tworzy wspólnotę ludzką opartą na wolności. Wolność jest podstawowym wyposażeniem warunkującym godność życia człowieka. Wolność człowieka opiera się na współdziałaniu jego duchowych władz: rozumu i wolnej woli. Człowiek weryfikuje swoją wolność w relacji do siebie samego, do drugiego człowieka i do świata. Każde z tych odniesień ujawnia okoliczności, pośród których człowiek napotyka czynniki zniewalające jego wolność lub wspierające ją. Wolność ludzka ma swoje granice, nie jest absolutna. Sprawdzianem wolności jest zdolność wyboru konieczności.

W relacji do siebie samego człowiek jest tak daleko wolny, że może nawet odebrać sobie życie. Czyn ten jednak jest potwierdzeniem, że człowiek uległ zniewoleniu. Doświadczył strachu, lęku przed koszmarną przyszłością, podyktowaną terminalną chorobą, potrzebą opieki paliatywnej, trudnymi okolicznościami, trwogą przed bólem czy zwykłą głupotą. W codziennych okolicznościach człowiek ma ciążenie ku życiu, instynkt życia jest tak wielki, że człowiek robi wszystko, aby je zachować. Targnięcie się na własne życie tylko pozornie dowodzi wolności człowieka, faktycznie natomiast potwierdza jego stan zniewolenia, godzi w jego godność. W relacjach między ludźmi problem wolności ujawnia się jeszcze bardziej. Interakcje $z$ innymi winny być kształtowane w oparciu o dobro wspólne, które stanowi ich normę i powinno być zagwarantowane przez społeczeństwo jako dobro wspólnoty opierające się na poszanowaniu dobra godności poszczególnych ludzi. Przebywanie bowiem w społeczności, we wspólnocie warunkuje prawidłowy rozwój osoby ludzkiej. Tylko ludzie posiadający godność, w wolności wybierający fundamentalne wartości mogą tworzyć prawdziwie ludzką komunię w porządku stwórczym i zbawczym ${ }^{6}$. Komunia osób zakłada całkowicie bezinteresowny dar $z$ siebie samego dla dobra drugiego człowieka.

Godność spełnia w człowieku funkcje motywacyjne ukierunkowując jego postępowanie na uznawany przez niego system wartości. Pozwala mu na obronę własnej tożsamości wynikającej z przekonań i sumienia. W sytuacjach

6 Por. E. Ozorowski, Godność osoby ludzkiej, [w:] Słownik matżeństwa i rodziny, Warszawa - Łomianki 1999, s. 152. 
związanych z zagrożeniem życia poczucie własnej godności pomaga pozostać wiernym przepracowanemu indywidualnemu systemowi wartości i własnemu sumieniu wbrew naciskom systemów totalitarnych. Człowiek z poczuciem godności potrafi sytuacje trudne, niepowodzenia, cierpienia, frustracje umiejętnie przeżyć, przyjąć, akceptując przeciwności życia.

\section{Godność podstawą społecznego życia}

Wśród principiów porządkujących płaszczyznę życia społecznego priorytetowo traktuje się zasadę godności człowieka. Katolicka nauka społeczna podkreśla potrzebę funkcjonowania społeczeństwa, nie tylko w skali mikro, ale także makrospołeczeństw, w oparciu o godność osób, które je tworzą, aby mogły się w nim w pełni rozwijać, być chronione oraz realizować własne cele. W każdym szanowanym społeczeństwie godność osobowa winna być respektowana jako najcenniejsze dobro człowieka ${ }^{7}$. To ona sprawia, że człowiek przewyższa swoją wartością całe otaczające go środowisko. Jako niezniszczalna własność każdego człowieka stanowi podstawę równości wszystkich ludzi. To ważny fundament w organizowaniu życia społecznego. Kościół w swoim społecznym nauczaniu przypomina, że każdy byt ludzki posiada godność, która niezależnie od tego, że osoba istnieje w konkretnej historii i społeczeństwie, nigdy nie może być pomniejszana, krzywdzona, prześladowana, lecz przeciwnie powinna być szanowana i chroniona. Współcześnie odnotowuje się szereg niebezpieczeństw zagrażających godności osoby ludzkiej. Wśród nich należy wymienić: nieludzkie systemy polityczne, fałszywe ideologie, przesadzoną tolerancję, jawnie niesprawiedliwe prawodawstwo pozbawiające człowieka podstawowych praw oraz agresywność środków społecznego przekazu ${ }^{8}$. Zagrożeniem są także negatywne zjawiska społeczne jak: rasizm, terroryzm, wygnanie, wykluczenie. Można mówić o braku należytych proporcji między rozwojem technicznym a etyką, co także jest czynnikiem instrumentalnego wykorzystania człowieka do osiągania celów ekonomicznych, a co w konsekwencji wymierzone jest przeciwko jego godności. Istnieje możliwość obiektywnego sprawdzenia poszanowania godności w zróżnicowanych społeczeństwach w funkcjonujących w nich prawach. Prawa człowieka pełnią rolę testu i stanowią podstawowe kryterium oceny systemu politycznego i programu działania państwa. W społeczeństwach, w których prawa człowieka są chronione, respektowana jest także godność człowieka. Tam, gdzie prawa są naruszane brakuje także poszanowania godności. Prawa człowieka chronią pełniejszy rozwój osoby ludzkiej. Są po to,

$7 \quad$ Jan Paweł II, Christifideles laici, 37.

8 Ibidem, 5. 
aby każdy miał przestrzeń potrzebną do spełnienia swoich zadań i powinności, aby mógł się rozwijać i stawać się człowiekiem. Są także wsparciem w realizacji dobra wspólnego, które nie jest zwykłą teorią, ale zobowiązaniem do tworzenia warunków pełnego rozwoju tym, którzy uczestniczą w życiu danego społeczeństwa. Dotyczy to także ludzi na wygnaniu, uchodźców, czy żyjących na peryferiach. Ci, którzy tworzą daną społeczność winni respektować także inną zasadę, którą promuje katolicka nauka społeczna związaną z zasadą godności ludzkiej, a którą jest zasada pomocniczości. Jan Paweł II w encyklice Centesimus annus przypomniał, że:

społeczność wyższego rzędu nie powinna ingerować w wewnętrzne sprawy społeczności niższego rzędu, pozbawiając ją kompetencji, lecz raczej winna wspierać ją w razie konieczności i pomóc w koordynacji działań z działaniami innych grup społecznych dla dobra wspólnego?.

W zasadzie tej postuluje, aby społeczności nadrzędne nie odbierały jednostkom ludzkim możliwości działania pozbawiając je godności, co niestety było charakterystyką żyjących na wygnaniu, czy uchodźców. Kolejną ważną zasadą funkcjonowania społecznego promowaną przez katolicką naukę społeczną jest zasada solidarności, która w encyklice Jana Pawła II Laborem exercens została określona jako wspólne działanie „przeciwko degradacji człowieka jako podmiotu w pracy, połączonej z niesłychanym wyzyskiem w dziedzinie zarobków, warunków pracy i troski o osobę pracownika" ${ }^{10}$. Niestety, w różnych częściach świata i w różnych krajach miały i mają miejsce rażące niesprawiedliwości, które pokazują jak ogromny jest zasięg krzywdy ludzkiej i nieposzanowania godności. Wypowiedzi papieża Franciszka ukierunkowują na potrzebę realizacji godności przez ludzi słabych, pokrzywdzonych, żyjących na peryferiach, a także na konieczność spieszenia im z pomocą materialną i duchową ${ }^{11}$.

\section{Godność okaleczona i podeptana - wygnanie, uchodźstwo, emigracja, peryferie}

Sto lat niepodległości Polski to historia milionów ludzi, żyjących w tym okresie w kraju i poza jego granicami. Los Polaków poza własnym krajem był często koniecznością dziejową, a nie przyjemnością. Jedni znaleźli się tam wskutek zawirowań politycznych inni wojennych, jeszcze inni ekonomicznych.

$9 \quad$ Jan Paweł II, Centesimus annus, 48.

10 Jan Paweł II, Laborem exercens, 8.

11 K. Gołębiewski, Franciszek - papież Kościoła ubogich, obrońca rodziny, [w:] Franciszek, Chciatbym Kościoła ubogiego dla ubogich, Kraków 2013, s. 25-27. 
W następstwie migracji politycznych i ekonomicznych (te ostatnie od końca XIX wieku) poza obszarem państwa polskiego zamieszkuje od 14 do $17 \mathrm{mln}$, a nawet do $20 \mathrm{mln}$ (szacunki są rozbieżne) Polaków oraz osób przyznających się do polskiego pochodzenia ${ }^{12}$. Społeczności polskie w krajach ościennych, zwłaszcza na Wschodzie, powstawały w wyniku rozbiorów Polski i zajęcia w 1939 roku wschodniej części Polski przez Związek Sowiecki. Mające miejsce w okresie zaborów powstania: listopadowe, krakowskie, styczniowe doprowadziły do ucieczki znaczącej liczby Polaków przed represjami do Europy Zachodniej ${ }^{13}$. Wielu powstańców zostało zesłanych w głąb Rosji. Obecnie największe mniejszości polskie istnieją na Litwie w rejonie Wilna, na Białorusi w rejonie Grodna, na Ukrainie w rejonie Żytomierza i we Lwowie, a w Czechach na Zaolziu; zdołano tam zachować ciągłość kultury i języka. W Niemczech i Rosji mieszkają zarówno Polacy pochodzenia autochtonicznego, jak i imigranci. W innych rejonach świata grupy polskie są określane mianem Polonii, obejmującym wszystkich, którzy zachowali, bez względu na miejsce urodzenia czy znajomość języka, poczucie łączności z Polską.

Od drugiej połowy XVIII wieku, ze względów politycznych opuszczali kraj: konfederaci barscy, powstańcy kościuszkowscy, powstańcy listopadowi i styczniowi; powstawały pierwsze skupiska polskie, głównie we Francji, także w Wielkiej Brytanii, Belgii, Szwajcarii, Niemczech i Stanach Zjednoczonych. Społeczność polską w Rosji tworzyli m.in. zesłańcy polityczni po powstaniach narodowych. W drugiej połowie XIX wieku zaczęły dominować ekonomiczne motywy wyjazdu, związane $z$ wkraczaniem środkowej i wschodniej Europy w system gospodarki kapitalistycznej. Fala emigracyjna zaczęła narastać w latach siedemdziesiątych XIX wieku, głównie z ziem zaboru pruskiego w głąb Niemiec; następnie rozszerzyła się na pozostałe zabory i kierowała się też do innych rejonów Europy, także na azjatyckie tereny Imperium Rosyjskiego; znacznie nasiliła się emigracja zamorska, głównie do Stanów Zjednoczonych, a nieco później do Argentyny i Brazylii.

I wojna światowa spowodowała falę migracji przymusowych. W 1914 roku Galicję opuściło ok. 800 tys. osób chroniąc się przed inwazją rosyjską w Austrii, na Węgrzech, w Czechach i na Śląsku Cieszyńskim. Z zaboru rosyjskiego, gdzie przeprowadzono ewakuację ludności przed wkraczającymi wojskami niemieckim, wyprowadzono ponad 600 tys. osób (bez zmobilizowanych do armii rosyjskiej).

Kolejna fala deportacji i przymusowych przesiedleń nastąpiła podczas II wojny światowej. Deportacje rozpoczęte na ziemiach państwa polskiego

\footnotetext{
12 E. Gigilewicz, Polonia, [w:] Encyklopedia „Biatych Plam”, t. 14, Radom 2004, s. 203.

13 M. R. Górniak, Migracja, [w:] Encyklopedia Katolicka, t. 12, Lublin 2008, s. 953.
} 
wcielonych do III Rzeszy w październiku i listopadzie 1939 stały się początkiem „golgoty” licznej rzeszy osób, których godność próbowano podeptać. Niemcy deportowali Polaków: inteligencję, zamożnych rolników, członków organizacji uznawanych za wrogo nastawione wobec Rzeszy. W tzw. obozach przejściowych, przeprowadzali selekcję osób kierowanych do pracy przymusowej w III Rzeszy oraz przewidywanych do germanizacji. W sumie do roku 1944 wysiedlono i wywieziono do III Rzeszy, do pracy przymusowej, do obozów koncentracyjnych, czy w celu germanizacji ok. 3,5 mln Polaków. Po zakończeniu wojny ocaleni wrócili do przedwojennego miejsca zamieszkania.

Po zakończeniu II wojny światowej poza Polską znalazło się ponad $5 \mathrm{mln}$ osób; ostatecznie do kraju nie powróciło ok. 0,5 mln Polaków, którzy osiedlali się w różnych regionach świata, głównie w Europie Zachodniej (RFN, Francja, Holandia, Belgia), USA, Kanadzie, Australii i Argentynie. Centrum działalności emigracyjnej powojennej stanowiła Wielka Brytania. Londyn był w latach 1945-1990 siedzibą władz RP na Obczyźnie.

Innym zjawiskiem mającym wpływ na liczebność grupy Polaków żyjących na wschód od obecnych granic Polski była tzw. repatriacja (choć przez wielu historyków nazywana także ekspatriacją), a faktycznie oczyszczeniem z etnicznego elementu polskiego terenów państwa polskiego przyłączonych do ZSRR. Towarzyszył temu proces wywożenia ludności ukraińskiej i białoruskiej do ZSRR. W latach 1944-1948 do kraju z wojskiem i w ramach repatriacji przybyło 1,5 mln Polaków i Żydów, głównie z terenów państwa polskiego włączonych 1939 do ZSRR; w kolejnych latach 1955-1957 ponad 200 tys. osób ${ }^{14}$.

W okresie PRL procesy emigracyjne były kontynuowane, choć odbywały się $\mathrm{w}$ zmienionych i bardzo utrudnionych warunkach prawno-politycznych. Umacnianie się władzy komunistycznej i wiążące się $z$ tym procesy natury politycznej wywołały niezbyt liczną, ale ważną falę emigracji, na ogół nielegalnej, osób sprzeciwiających się narzuconej Polsce władzy. Wydarzenia 1956 otworzyły prawne możliwości wyjazdów, w tym i emigracyjnych; szacuje się, że w latach 1956-1980 z Polski wyjechało ok. 800 tys. osób („Rocznik Statystyczny” 1969 i 1984). Przemiany zachodzące po 1980, a szczególnie wprowadzenie stanu wojennego w grudniu 1981 roku, wywołały zjawisko tzw. emigracji solidarnościowej; objęła ona kilka tys. osób, które zostały zmuszone do opuszczenia kraju.

Największe i najbardziej dynamiczne mniejszości polskie powstały w Ameryce Północnej i Europie Zachodniej. Najważniejszym ośrodkiem Polonii w Europie są Niemcy; jednym z liczniejszych Francja; ważne miejsce, ze względu na istniejące tam instytucje polskie, zajmowała Wielka Brytania; znaczne skupiska

14 Szerzej na temat uformowania kresów w Rzeczypospolitej i ich roli w kształtowaniu godności Polaków M. A. Koprowski, Burzliwe dzieje kresów wschodnich, [w:] Zespół Wydawnictwa SBM, Kresy. Historia. Ludzie. Tradycje, Warszawa 2013, s. 126-240. 
istnieją w innych krajach, m.in. Austrii, Belgii, Danii, Holandii, Szwajcarii, Szwecji, Włoszech.

Specjalne miejsce, ze względu na skomplikowane losy, zajmuje Polonia w Rosji, na Białorusi, Ukrainie, Litwie i w Kazachstanie.

Największe skupiska polonijne powstały za oceanem. Polonia w Stanach Zjednoczonych jest największa w świecie i ma najbardziej zróżnicowaną strukturę. Do ważnych, choć znacznie mniejszych, należy Polonia w Kanadzie; w Ameryce Łacińskiej wyróżnia się Polonia w Brazylii i Argentynie. Jedynym krajem afrykańskim, w którym ukształtowała się liczniejsza i trwała grupa polonijna, jest Republika Południowej Afryki. Polonia w Australii i Nowej Zelandii ukształtowała się głównie po II wojnie światowej.

Polacy w krajach swego osiedlenia zabiegali o obronę własnej godności. W zależności od okresu dziejowego jednym udawało się ją obronić, inni zostali $z$ niej okaleczeni lub wręcz ogołoceni. Dziełem emigracji było wiele ważnych instytucji naukowych troszczących się i wręcz walczących o zachowanie godności narodowej, m.in. Biblioteka Polska w Paryżu (od 1838), Muzeum Narodowe Polskie w Rapperswilu (1870), Instytut Literacki w Maisons-Laffitte koło Paryża (1946), Instytut J. Piłsudskiego w Nowym Jorku (1943) i Londynie (1947), Polski Instytut Naukowy w Ameryce (1942), Instytut Polski i Muzeum Generała Sikorskiego w Londynie (pod tą nazwą od 1964).

Od połowy XIX wieku ukazywało się na emigracji kilkaset tytułów prasy polskiej, z których wiele ma dzisiaj już długą tradycję. W poszczególnych krajach powstały po II wojnie światowej różnego typu organizacje mające na celu obronę politycznych i ekonomicznych interesów emigracji i Polonii. Do najważniejszych należą: Kongres Polonii Amerykańskiej, Kongres Polonii Kanadyjskiej, Kongres Polonii Francuskiej, Rada Naczelna Polskich Organizacji w Australii; także Kongres Polonii Wolnego Świata. Jednym z głównych celów ich działalności było podtrzymywanie poczucia polskiej przynależności narodowej, tradycji, kultury, języka.

Proces asymilacji Polaków jest zjawiskiem naturalnym, w różnych krajach przebiegał i przebiega bardzo różnie. W krajach zachodnich, w USA czy Francji, ma charakter powolnego wtapiania się w miejscowe społeczeństwo, natomiast okresowo w Niemczech, a także w pozostałych krajach ościennych i w Rosji wzmacniano procesy asymilacyjne przedsięwzięciami administracyjnymi, często mającymi charakter działań wynaradawiających.

Stosunki z krajem zawsze stanowiły istotny przejaw aktywności emigracji i Polonii. W okresie zaborów emigracja stanowiła bazę dla ruchów niepodległościowych. Znalazło to wyraz w dość licznym udziale Polaków z zagranicy w Wiośnie Ludów (1848) oraz w polskich formacjach wojskowych walczących na frontach I wojny światowej. W okresie międzywojennym kontakt z krajem 
odbywał się bez przeszkód; wyjątek stanowiła grupa polska zamieszkała w ZSRR i na Litwie, którą praktycznie pozbawiono możliwości kontaktów.

Po II wojnie światowej znaczna część Polonii pozostała w opozycji do narzuconego Polsce systemu politycznego, co spowodowało ograniczenie obecności w kraju. Nie bez znaczenia dla obustronnych kontaktów był stosunek Państwa Polskiego do Polonii i emigracji. W okresie międzywojennym próbowano realizować aktywną politykę emigracyjną i propolonijną. Prowadzona przez Ministerstwo Spraw Zagranicznych i Urząd Emigracyjny miała na celu wykorzystanie istniejących i powstających w tym czasie skupisk polonijnych do realizacji polskiej polityki zagranicznej i propagowania wiedzy o Polsce w świecie. Szczególną rolę miał odegrać Światowy Związek Polaków z Zagranicy. W miarę możliwości kraj wspierał istniejące szkolnictwo polskie, prasę i polskie organizacje.

Sytuacja uległa zmianie po objęciu władzy w Polsce przez komunistów. Znaczna część Polonii i emigracji przyjęła niechętną postawę wobec komunistycznej Polski i nie ulegała prowadzonej po 1945 roku propagandzie (m.in. akcje powrotowe, 1955-1956, połowa lat 60.) Dopiero po 1956 roku i przemianach demokratyzacyjnych w Polsce nastąpiło pewne ożywienie kontaktów (powstało Towarzystwo Łączności z Polonią Zagraniczną „Polonia”). Istotne zmiany zarysowały się w końcu lat osiemdziesiątych XX wieku. W latach dziewięćdziesiątych nastąpiło otwarcie kraju dla rodaków z zagranicy, do Polski powróciła wówczas grupa osób, które po 1945 r. znalazły się na emigracji z powodów politycznych. W latach dziewięćdziesiątych XX wieku trwały migracje Polaków do krajów Europy Zachodniej (głównie RFN) i USA mające podłoże ekonomiczne. Trend ten umocniło przyjęcie Polski do Unii Europejskiej (2004), w efekcie obywatele Polscy zyskali oficjalny, legalny dostęp do rynków pracy w krajach unijnych oraz możliwość kształcenia się w uczelniach wyższych krajów unijnych.

\section{W obronie godności}

Ważnym ośrodkiem podtrzymującym polskość i więź z krajem był - i jest nadal - Kościół katolicki. W polskich parafiach koncentrowało się życie polonijne, odegrały one ważną rolę integracyjną w odniesieniu do różnych fal emigracyjnych. Profesor Cezary Kuklo jest zdania, że rola Kościoła rzymskokatolickiego w dziejach narodu i Państwa Polskiego w ostatnim stuleciu (lata 1918-2018) to temat niezwykle ważny i głęboki, ale zarazem obszerny, obliczony na tomy książek napisanych przez wieloosobowe zespoły badaczy i autorów ${ }^{15}$.

15 Por. C. Kuklo, Rola Kościoła rzymskokatolickiego w dziejach narodu ipaństwa polskiego 19182018. Wykład inauguracyjny w AWSD na rozpoczęcie roku akademickiego 2018-2019. 
Zanim Państwo Polskie odzyskało utraconą niepodległość warto podkreślić, że to czynnik religijny (wyznaniowy) kształtował w XIX wieku postawę większości Polaków. Nie będzie żadnej przesady w stwierdzeniu, że w dobie zaborów, w dobie, kiedy nie było Państwa Polskiego Kościół katolicki był podstawową instytucją podtrzymującą godność narodową.

Świeżo co odzyskanej niepodległości u schyłku 1918 roku przyszło bronić przed nawałą bolszewicką, niosącą na bagnetach na Zachód ideologię komunistyczną. Duchowni wszystkich szczebli, bez względu na sympatie polityczne, latem 1920 roku aktywnie włączyli się w działania zmierzające do obrony niepodległej Polski (m.in. apelując do społeczeństwa o masowy zaciąg do wojska). Typowym przykładem postawy duchowieństwa był 27-letni ks. Ignacy Skorupka, który na ochotnika zgłosił się na kapelana wojskowego 36 pułku Legii Akademickiej i szedł w pierwszym szeregu razem z dowódcą batalionu zagrzewając żołnierzy do walki 14 sierpnia w boju pod Ossowem, będącej częścią „Bitwy Warszawskiej”, w której zginął. Z kolei, bliski naszym sercom bp Romuald Jałbrzykowski, późniejszy metropolita wileński, kierował w 1920 roku Komitetem Obrony Łomży ${ }^{16}$.

II Rzeczpospolita była państwem wielonarodowym, w którym obok blisko $19 \mathrm{mln}$ Polaków (w większości katolików), żyło blisko 5 mln Ukraińców, 2 mln Żydów, 1,5 mln Białorusinów i ok. 1 mln Niemców.

Konstytucja marcowa z 1921 rou głosiła, ,że wyznanie rzymskokatolickie, będące religią przeważającej części narodu, zajmuje w państwie naczelne stanowisko wśród równouprawnionych wyznań", co powtórzono w konstytucji kwietniowej z 1935 roku.

W dwudziestoleciu międzywojennym utworzono trzy nowe wydziały teologii katolickiej: w Warszawie, Wilnie i w nowo otwartym w 1918 roku Uniwersytecie Katolickim w Lublinie, choć ten ostatni był programowo nastawiony na kształcenie inteligencji świeckiej.

Nastąpiła rozbudowa wydawnictw religijnych różnego typu zgodnie z wielkimi, wyraźnie w miarę szybkiej alfabetyzacji rosnącymi potrzebami masowymi. Nie sposób nie zaakcentować działalności szkolno-wychowawczej prowadzonej przez Kościół w tym okresie czasu (np. salezjanie prowadzili 30 zakładów kształcących i wychowujących młodzież męską w praktycznych zawodach; siostry zakonne, głównie urszulanki, prowadziły ok. 40\% istniejących w całym kraju przedszkoli, setki internatów dla młodzieży, kilkaset szkół w tym 50 liceów i 12 seminariów nauczycielskich) ${ }^{17}$.

\footnotetext{
16 Por. ibidem.

17 Por. ibidem.
} 
Kościół był uważnym uczestnikiem życia społecznego II Rzeczypospolitej. Encyklika papieża Piusa XI Quadragesimo Anno (z marca 1931 roku) stała się podstawą listu pasterskiego prymasa Polski kard. Augusta Hlonda z 23 kwietnia 1932 roku O chrześcijańskie zasady życia państwowego. Prymas zwracał w nim uwagę, że „Państwo jest dla obywateli, a nie obywatele dla państwa”. Potępiono gwałt w życiu politycznym i utożsamianie państwa z grupą rządzącą. Stwierdzono, iż najważniejszym zadaniem państwa jest koordynacja interesów rożnych grup społecznych, a nie umacnianie własnej wszechwładzy. Krytyce totalitaryzmów widocznych w krajach po zachodniej i wschodniej granicy Polski i oględnemu wskazaniu podobnych tendencji w Polsce towarzyszyły zarazem postulaty reform, mających na celu ulżenie grupom najbardziej upośledzonym, a nawet wykluczonym ekonomicznie.

Dla opracowania programu tych reform Episkopat powołał do życia w $1933 \mathrm{r}$. Radę Społeczną przy Prymasie Polski. Nowoczesne idee katolicyzmu społecznego upowszechniała wśród świeckich założona w 1930 r. Akcja Katolicka. Jej celem była obrona zasad moralnych i religijnych w życiu społecznym pod przewodnictwem hierarchii kościelnej, a niezależnie od partii politycznych. Ta masowa organizacja (w 1939 roku liczyła do 750 tys.) była obecna przede wszystkim w środowiskach wiejskich, dużo słabiej w środowiskach robotniczych ${ }^{18}$.

Obok Akcji Katolickiej powstało szereg różnych organizacji i grup ważnych dla kultury religijnej kraju.

Lata II wojny światowej aż po 1956 r. przyniosły społeczeństwu polskiemu i Kościołowi katolickiemu tragiczne wydarzenia i przemiany, które pokazały jak łatwo można podeptać godność ludzką.

Sowieci, dążąc do szybkiego zniszczenia struktur państwa polskiego i jego elity, wśród których byli duchowni, podjęli działania mające na celu radykalne ograniczenie roli Kościoła i wiary. Zdawali sobie sprawę, że katolicyzm na tzw. Kresach Wschodnich był niemalże identyczny z polskością. Podjęli zdecydowaną walkę z Kościołem. Zlikwidowano wszelkie organizacje i instytucje kościelne, bractwa i stowarzyszenia, instytucje charytatywne. Zamknięto wyższe seminaria duchowne, klasztory i zakony. Kurie biskupie i hierarchów wyrzucono z ich pomieszczeń, mienie konfiskowano. Jesienią 1939 r. nie wznowiły już pracy szkoły prowadzone przez kościoły i zakony, zamknięto szkolne kaplice.

Polityka kościelna okupanta niemieckiego była bardziej zróżnicowana. $\mathrm{Na}$ terenach włączonych bezpośrednio do Rzeszy, tj. Śląska, Pomorza Gdańskiego i Wielkopolski („Kraj Warty”), przeznaczonych do zgermanizowania i skolonizowania, władze niemieckie, podobnie jak sowieckie, zmierzały do całkowitej

18 Por. ibidem. 
likwidacji polskiej organizacji kościelnej, do usunięcia lub wyniszczenia polskiego duchowieństwa i zastąpienia go księżmi narodowości niemieckiej. W Generalnym Gubernatorstwie hitlerowcy starali się wszelkimi środkami ograniczyć działalność i rolę Kościoła, a w dalszej perspektywie przekształcić go w posłuszne narzędzie realizacji własnych celów politycznych ${ }^{19}$.

W skali strat poniesionych przez poszczególne grupy społeczne i zawodowe duchowieństwo, jeśli nie liczyć ludności żydowskiej, okazało się grupą, która poniosła największe procentowo ofiary osobowe. Stale uzupełniane i wciąż jeszcze niekompletne statystyki dowodzą śmierci ok. 2 tys. księży diecezjalnych (w tym 6 biskupów), blisko 1 tys. zakonników i ponad 300 sióstr zakonnych.

W kraju, stopniowo zajmowanym od lipca 1944 roku przez wojska sowieckie, społeczeństwo polskie w Kościele, pomimo jego strat osobowych i materialnych, widziało ostatnią niezależną instytucję zdolną przeciwstawić się komunizmowi ${ }^{20}$.

Ale z roli i pozycji Kościoła zdawali sobie sprawę także komuniści, którzy od 1948 roku podjęli zdecydowaną walkę z Kościołem. Na mocy dekretu O ochronie sumienia $i$ wyznania zlikwidowano wiele stowarzyszeń kościelnych, instytucji charytatywnych i oświatowych. Podejmowano też próby przeciwstawienia niższego duchowieństwa hierarchii, czemu miał służyć zorganizowany przy Związku Bojowników o Wolność i Demokrację - ruch „księży patriotów”21.

Napór władzy komunistycznej nie został zahamowany nawet po podpisaniu w kwietniu 1950 roku tzw. Porozumienia między państwem a Kościołem. Do więzień szli nawet biskupi, nie mówiąc już o zwykłych duchownych; organizowano im procesy pokazowe, z Ziem Zachodnich usunięto administratorów apostolskich, wypierano religię ze szkól, wojska, szpitali, zawieszono „Tygodnik Powszechny".

Odpowiedzią prymasa Polski kard. Stefana Wyszyńskiego były słowa wypowiedziane 4 czerwca 1953 roku: „Rzeczy Bożych na ołtarzach Cezara składać nam nie wolno. Non possumus!" Prymas został internowany, a jego najbliższego współpracownika bp. Antoniego Baraniaka, aresztowanego wraz z nim, poddano bezlitosnym przesłuchaniom.

Władza komunistyczna nie rezygnowała z walki z Kościołem. Kościół nie tracił inicjatywy, zawsze opowiadając się po stronie godności, przede wszystkim urozmaicał formy duszpasterskie wśród młodzieży (ruch oazowy), coraz większą rolę odgrywały Kluby Inteligencji Katolickiej. Znaczna część społeczeństwa

\footnotetext{
19 Por. ibidem.

20 Por. ibidem.

21 Por. ibidem.
} 
postrzegała Kościół jako stabilną, mocną przeciwwagę dla zdemoralizowanej władzy.

Nie do przecenienia było, niejako cudowne, podniesienie prestiżu Kościoła poprzez wybór w październiku 1978 roku na papieża abp. Karola Wojtyły, i jego pierwsza pielgrzymka do kraju w 1979 roku. Księża wsparli wystąpienia robotników latem 1980 roku i rodzącą się „Solidarność”.

W stanie wojennym decydenci komunistyczni zdawali sobie sprawę z pozycji Kościoła. Najtragiczniejszą okolicznością tego okresu była akcja porwania i bestialskiego zamordowania 19 X 1984 r. przez funkcjonariuszy SB ks. Jerzego Popiełuszki, znanego z odprawiania „Mszy św. za Ojczyznę”, w kościele św. Stanisława Kostki na Żoliborzu, broniącego godności robotnika ${ }^{22}$.

\section{Zakończenie}

Dzieje polskiego narodu przepełnione są tragicznymi, ale także jakże pięknymi i chlubnymi kartami. Na przestrzeni wieków nie zabrakło tych, którzy potrafili stanąć w obronie godności człowieka, mimo szykan i prześladowań ze strony, czy zaborców, czy systemów totalitarnych wrogich polskiemu narodowi. Źródłem trwania przy kardynalnych wartościach i do duchowej walki o godność narodu i człowieka była niewątpliwie wiara zaszczepiona u początków państwowości polskiej, a następnie „wiara ojców” przekazywana z pokolenia na pokolenie w trudnych nieraz i pełnych niepokojów okolicznościach. Bez niej trudno byłoby się oprzeć minionym pokoleniom pokusom pójścia z obowiązującym nurtem ideologii, czy poprawności politycznej.

Niewątpliwie sens dziejów dobrze rozumiał nasz rodak, ojciec święty Jan Paweł II, który mówił:

Człowieka (...) nie można do końca zrozumieć bez Chrystusa. A raczej: człowiek nie może siebie sam do końca zrozumieć bez Chrystusa. Nie może zrozumieć ani kim jest, ani jaka jest jego właściwa godność, ani jakie jest jego powołanie i ostateczne przeznaczenie ${ }^{23}$ (Warszawa, 1979).

Niemożliwe byłoby więc zrozumienie dziejów naszego narodu bez przyjęcia prawdy o Chrystusie - Mesjaszu i Zbawcy.

Każdy człowiek, niewłaściwie korzystający z daru wolności, wikła się nieraz w niewolę zła i grzechu; ściąga na siebie skutki działania zła - podeptanie własnej godności przez siebie samego, jak i innych, co ostatecznie prowadzi do śmierci. Bóg w Starym Testamencie obiecywał ludziom, że wyzwoli ich z mocy

22 Por. ibidem.

23 Jan Paweł II, Homilia w czasie Mszy św. odprawionej na placu Zwycięstwa, [w:] Jan Paweł II, Pielgrzymki do Ojczyzny, Kraków 2006, s. 22-23. 
śmierci i przywróci utracone życie z Nim w przyjaźni i miłości. Zapowiadał tė̇, że tego wyzwolenia dokona Mesjasz, który przyjdzie w pełni czasów. Bez Boga, bez tajemnicy wcielenia Syna Bożego przychodzącego do człowieka, nie można zrozumieć sensu podejmowanej walki o godność człowieka.

Tajemnica inkarnacji pozwala człowiekowi uwierzyć, że w osobie Jezusa Chrystusa może on dostąpić zbawienia - pojednania z Bogiem, wyzwolenia z mocy śmierci, życia z Nim w wolności i godności dziecka Bożego. To wkroczenie Syna Bożego - Jezusa Chrystusa - w ludzką historię stało się źródłem nadziei i wiary, by żyć w wolności i cieszyć się godnością ofiarowaną człowiekowi przez Boga-Stwórcę.

Słowa kluczowe: godność, osoba ludzka, naród, historia, Kościół

\section{Bibliografia:}

1. Chlewiński Z., Zaleski Z., Godność, [w: [ Encyklopedia Katolicka, t. 5, Lublin 1989.

2. Gigilewicz E., Polonia, [w:] Encyklopedia „Bialych Plam”, t. 14, Radom 2004.

3. Gołębiewski K., Franciszek - papież Kościoła ubogich, obrońca rodziny, [w:] Franciszek, Chciałbym Kościoła ubogiego dla ubogich, Kraków 2013.

4. Guardini R., I diritti del nascituro, "Studi cattolici" 5/6 (1974).

5. Górniak M. R., Migracja, [w:] Encyklopedia Katolicka, t. 12, Lublin 2008.

6. Gąsecki K., Jesteśmy napetnieni Duchem Chrystusa w sakramentach Kościoła, Pelplin 2018.

7. Jan Paweł II, Centesimus annus.

8. Jan Paweł II, Christifideles laici.

9. Jan Paweł II, Dominum et Vivificantem.

10. Jan Paweł II, Homilia w czasie Mszy św. odprawionej na placu Zwycięstwa, [w:] Jan Paweł II, Pielgrzymki do Ojczyzny, Kraków 2006.

11. Jan Paweł II, Laborem exercens.

12. Koprowski M. A., Burzliwe dzieje kresów wschodnich, [w:] Zespół Wydawnictwa SBM, Kresy. Historia. Ludzie. Tradycje, Warszawa 2013.

13. Kuklo C., Rola Kościoła rzymskokatolickiego w dziejach narodu i panstwa polskiego 1918-2018. Wykład inauguracyjny w AWSD na rozpoczęcie roku akademickiego 2018-2019.

14. Ozorowski E., Godność osoby ludzkiej, [w:] Stownik malżeństwa i rodziny, Warszawa - Łomianki 1999.

15. Tomasz z Akwinu, Scriptum super sententiis. 